\title{
ВПЛИВ СОЦІАЛЬНИХ МЕДІА НА ФОРМУВАННЯ ГРОМАДСЬКӦ̈ ДУМКИ
}

\author{
Мирослава Рудик \\ Львівський національний університет імені Івана Франка \\ вул. Генерала Чупринки, 49, 79044, Львів, Україна \\ e-mail: rudyk miroslava@ukr.net \\ https://orcid.org/0000-0003-3612-100X
}

У статті авторка досліджує роль соціальних медіа у процесі формування громадської думки. Окреслює громадську думку як елемент соціальної системи. Аналізує принципи поширення інформації у соціальних медіа. Вивчає контент інформаційних повідомлень та роль громадської думки як джерела інформації чи інформаційного приводу у ЗМІ.

Ключові слова: соціальні медіа, громадська думка, вплив, інформація.

Засоби масової комунікації сьогодні охоплюють широкий спектр інструментів для поширення інформації. Застосування технологій мультимедійності у практиці сучасних ЗМІ стало звичною справою. Адже йдеться не лише про боротьбу за увагу аудиторії, а й, безумовно, вплив на неї. У суспільстві інформація відіграє ключову роль і це змінює правила гри у всіх сферах життя. Тому формування громадської думки - це те завдання, яке ставлять перед собою сучасні медіа. Журналісти, як професійні комунікатори, мають з особливою відповідальністю оцінювати той факт, що динаміка сучасного світу, де домінують інформаційні технології, потребує фахівців, які відповідають вимогам часу і запитам масово-комунікаційної галузі. Не варто також недооцінювати соціальні медіа, які в інформаційному потоці прагнуть сказати своє слово. Адже громадянська журналістика чимраз більше набирає популярності, знаходить своє вираження через блоги, соціальні мережі, відео-канали. Хтось у цьому бачить нагальну потребу, хтось - спосіб самовираження, інші - захопливе заняття, ще інші - шлях до заробітку через рекламу. Тому дослідження впливу соціальних медіа на громадськість вважаємо темою актуальною і вкрай потрібною для вивчення як феномену мас-медійної культури.

Наукова думка у сфері дослідження саме соціальних медіа ще не є усталеною і довершеною, зважаючи на новизну явища в українському контексті, динаміку розвитку соціальних медіа та зміну їхніх функціональних можливостей. Історіографію нашого дослідження черпаємо з праць Б. Потятиника, М. Чабаненко, Л. Городенко, О. Романенко, Є. Шолухно, Т. Фісенко, В. Гвоздєва та ін.

(C) Рудик М., 2020 
Мета дослідження - з’ясувати, як соціальні медіа формують громадську думку, визначити, що є пріоритетом обговорення у соціальній комунікації на прикладі соцмереж і блогів.

У ході дослідження застосовано низку загальнонаукових та спеціальних методів, а саме: метод аналізу, синтезу, узагальнення, метод моніторингу і спостереження, статистичні дані. На різних етапах дослідження було використано проблемно-тематичний, типологічний і дискурсивний методи. Загалом наукове дослідження побудоване за принципами об’єктивності, комплексності й достовірності.

У час бурхливого розвитку інформаційних технологій та активного впровадження процесів глобалізації соціальні медіа стають потужним інструментом впливу на людину. У час монополізації інформації традиційними ЗМІ, відвертою пропагандою та маніпуляцією з боку телебачення, людина шукає інформацію на інших комунікативних платформах. Мережева комунікація взяла на себе роль інформування та модератора діалогу, де кожен член суспільства має доступ до інформації та право на висловлення власної позиції. Розвиток спілкування у мережі спричинив справжній бум громадянської журналістики. Як зазначає В. Гвоздєв: «Вже сьогодні широкомасштабний інформаційний обмін за допомогою громадських медіа, соціальних мереж, блогів становить серйозну конкуренцію традиційним ЗМІ. Такі форми спілкування набувають дедалі більшої популярності в інформаційно-комунікативному просторі. Громадянська журналістика $€$ могутнім засобом самопросування соціуму на шляху до громадянського суспільства, формою публічної участі громадян у суспільно-політичному житті» ${ }^{1}$.

Тож якщо коротко окреслити різницю між традиційними ЗМІ і соціальними медіа, то найперше, на чому варто наголосити, - це доступність інтернет-сервісів та можливість кожному творити контент. Традиційні 3МІ мають обмежене редакційне коло, політику видання, їхня інтеграція в інтернет-простір теж має чіткі ознаки бренду видання, сталість інформаційної структури. I навіть залучення широкого кола блогерів на сайті того чи іншого ЗМІ не робить його соціальним медіа, оскільки блогери - це ж ті самі журналісти, які пишуть про те, що не могло увійти у друкований варіант видання або доповнюють ті повідомлення, які вже були в газеті. До прикладу, блоги газети «Високий Замок» найчастіше ведуть Наталія Балюк та Ігор Гулик. Серед популярних публікацій є передруки матеріалів Юрія Макарова, Віталія Портникова, Юрій Андруховича та ін.

В іншому випадку блогерами на сайтах традиційних ЗМІ виступають політологи, історики, економічні експерти, тобто особи, які є фахівцями певної галузі і можуть поділитись інформацією з широкою аудиторією. Прикладом може слугувати газета «День», де свій блог про актуальні політичні події веде Євген Марчук. Блог Сергія Грабовського - це історичні розвідки, а письменник Андрій Любка у своєму блозі висловлює роздуми про літературу, хобі, натхнення. Але тут знову йдеться про обмежене і наперед визначене коло людей. Тому такий варіант блогінгу теж не можна зачислити до соціальних медіа.

«Соціальні медіа - це група інтернет-додатків, які побудовані на ідеологічних та технологічних засадах web 2.0 та дають змогу користувачам створювати контент

\footnotetext{
1 Гвоздєв, В.М. (2013), «Блогінг як вияв і знаряддя громадянської журналістики», Вісник Львівського ун-ту. Серія журн., вип. 38, с. 469.
} 
та обмінюватись ним»². До соціальних медіа належать особисті блоги, мікроблоги, соціальні мережі, відеохостинги, фотосервіси, інтернет-форуми тощо. Першою умовою соціальних медіа $є$ доступність автора до широкої аудиторії. А вже сама тематика мережевої комунікації визначається специфікою конкретного соціального медіа та його контентними ресурсами. До прикладу аудіовізуальні можливості YouTube-каналу та короткі повідомлення у Twitter.

Яким би не був зміст повідомлення, його технічні характеристики та аудиторія, на яку спрямована інформація, - все це має потужний вплив на людину. Адже соціальні медіа створюють живий організм спільноти, який виробляє оціночні механізми дійсності і $є$ барометром суспільних настроїв. Поява соціальних медіа, створення особистих інтернет-блогів, спільнот у соціальних мережах і залучення до них громадськості дає змогу здійснювати моніторинг тем і проблем, які виносяться на загал. Чи не тому соціальні медіа основний акцент роблять на успішній комунікації, тобто на створенні аудиторії, яка об'єднана спільною метою, тобто групою за інтересами. Комунікація у мережі теж має свої особливості. 3 одного боку - це завжди збереження анонімності або часткове приховування інформації, а з іншого - виражена індивідуальність автора через фото, ілюстрацію, лексику, популярність. Отож правила поведінки користувача стають загальноприйнятими. I все це сприяє вияву свободи слова та співучасті у творенні нової реальності, що у цілому набирає ознак громадянського суспільства. Тож роль соціальних медіа не зводиться тільки до інформування та активного обігу інформації. Важливою $є$ консолідація суспільства навколо важливих проблем чи то політичного, чи соціального життя. Залучення громадськості до просвітницької діяльності, участь в освітніх проектах тощо.

Сьогодні все частіше у соціальних мережах можемо спостерігати групи або окремих осіб, що діляться зі своїми підписниками просвітницькою або науково-популярною інформацією. До прикладу, групи у соцмережі Facebook «Духовно-психологічна порадня», «Слова великих людей», «Компас Наука», «Українська поезія», «Скарбниця мудрості», «Цей дивовижний світ» тощо. Є й суто інформаційні групи «Твої новини», «Новини Львова», «Мій Львів - оголошення», «Чим живе Львів», «Новини західного регіону» та ін. Є чимало нішевих груп «Українська вишивка», «Молитва на вервиці», «Дерев’яні вироби», «Рукоділля», «Практична косметологія» тощо. Виокремлюємо й суто практичні групи «ОГОлошення», «Купівля-продаж вся Україна», «Сімейний магазин», «Дитячі речі», «Новий базар України», «Людоньки, порадьте», «Українські привітання»... Т. Фісенко, вивчаючи інтернет-спільноти як елемент мережевої комунікації, стверджує: «Якщо інформаційний запит й інформаційна потреба виявляються актуальними та популярними, на цьому грунті відразу створюється нова соціальна спільнота»³.

Кожен потенційний користувач соціальних мереж є учасником кількох таких груп з більшою чи меншою комунікативною активністю. Вже не кажучи про створені локальні групи випускників шкіл, членів кафедр навчальних закладів, батьківських комітетів, різних асоціацій та громадських об’єднань, політичних партій,

Social Media and its Origins, available at: http://www.defence.gov.au/pathwaytochange/Docs/ SocialMedia/1.\%20Social\%20media\%20and\%20its\%20origins\%20SM.p.

3 Фісенко, Т. В. (2010), «Соціальні інтернет-мережі як засіб задоволення інформаційних потреб», Наукові записки Інституту журналістики, Т. 41, с. 193. 
мистецьких гуртків тощо. I тільки віртуальна складова дозволяє користувачу багатопланову комунікацію та його присутність у таких різних спільнотах, дає змогу отримувати й поширювати потрібну інформацію.

Серед популярних персоналій, які діляться у соцмережі Facebook цікавим контентом, Ігор Федик (історичні та краєзнавчі розвідки), Любомир Скочеляс, який як політолог дає трактування політичній ситуації в Україні, Софія Федина - депутатка і громадська активістка, співачка, яка славиться великою популярністю і частотою публікацій.

Як зазначає дослідниця Л. Городенко: «Комунікація має за мету цілі, яких індивіди намагаються досягти в процесі спілкування, зокрема це розв’язання повсякденних завдань, навчання, збирання та опрацювання інформації про навколишнє середовище, зберігання інформації. Спілкування визначає ставлення не тільки до інших людей, а й до структур, об'єднаних у мережу (як виробничу, так і комунікативну)» ${ }^{4}$.

Якщо проаналізувати принципи формування громадської думки за посередництвом соціальних медіа, то насамперед слід врахувати психологічні чинники. Адже кожен індивід прагне бути почутим і прийнятим, задовільнити свою потребу у спілкуванні і приналежності до певної групи. Тут теж варто наголосити на соціальній значущості і ототожненні з друзями з групи, соціальній вигоді від дружби 3 певними особами (коли йдеться про відомих політиків, громадських діячів, зірок естради, письменників). Не менш важливим психологічним чинником є самоідентифікація, підтвердження правильності своїх переконань, утвердження своїх ідей через схвалення однодумців. I хоч комунікація відбувається у віртуальний спосіб, все ж їі учасники дбають про створення певного іміджу, для них важлива їхня репутація, яка базується на закладених цінностях. 3 цього випливає складова мережевого спілкування - самопрезентація. Це можливість креативного вираження свого «Я», розкриття духовно-творчого потенціалу, презентація широкому загалу мистецьких здібностей, апробація таланту. Часом для користувача соціальними медіа важливо мати можливість сплеску емоцій, тобто поділитись якоюсь негативною ситуацією, яка трапилась. Такий прийом емоційної розрядки дає ефект проговорення проблеми, додаткову соціалізацію (ти не один у цьому світі), емпатію та підтримку друзів, а також досвід тої чи іншої ситуації, який для інших може бути корисним застереженням. Звичайно, популярними є також і розповіді про позитивні події (цікаві зустрічі, подорожі, особисті досягнення). Все це є приводом для комунікації, яка може виходити і за рамки віртуальності. Соціалізація є надважливим чинником у мережевій комунікації. У віртуальному вимірі вона має більшу свободу і ширші можливості, бо об’єднує людей не за географічними чи демографічними показниками, а насамперед за інтересами як вузькопрофільними, так і загальнолюдськими.

Соціальні медіа дають потенціал для саморозвитку, навчання та отримання нової інформації. Часто це і $є$ мотивацією для учасників групи отримувати нові знання, ділитися з аудиторією, як кажуть - «тримати планку». Саме тому сьогодні інформацію з усіх сфер життя людини (релігія, освіта, культура, медицина, політика) виму-

\footnotetext{
${ }^{4}$ Городенко, Л. М. (2014), «Комунікативні парадигми розвитку мережевих соціальних спільнот», Інформаційне суспільство, вип. 19, с. 70.
} 
шено адаптують до нових форм комунікації за допомогою соціальних медіа, бо це найпростіший шлях до аудиторії.

Ще одне завдання, яке виконують соціальні медіа - це розваги. Такі групи, як «Корінь сміху», «Шляхта не працює», «Баба і кіт», «Жарти українською», поширюють контент, який змушує усміхнутися, і $є$ більш поширюваним, ніж актуальні події політичного життя. Меми і фотожаби розходяться мережею з такою швидкістю, що стають вірусними. Цікава картинка і влучний опис до неї здатні не лише розважити користувачів, а й з гумором підійти до злободенних тем.

Огляд соціальних мереж дає змогу побачити їхній безпосередній вплив на процеси демократизації суспільства, здатність самоорганізовуватись, самотужки вирішувати важливі питання. До прикладу, волонтерська діяльність, допомога хворим дітям, військовим, збір коштів потребуючим, розголошення злочинної діяльності, пошук винуватців ДТП, осуд аморальних вчинків, виявлення шахрайства. «Соціальні інтернет-мережі можуть належати до одного з інститутів громадянського суспільства, а саме - до незалежних засобів масової інформації, що обслуговують громадські інтереси та потреби, формують громадську думку. Своє місце вони можуть мати серед вертикального виміру громадянського суспільства, до якого належать: політичні права громадян; - політичні партії та рухи; - органи місцевого самоврядування; - незалежні засоби масової інформації»5.

Громадська думка у соціальних медіа формується за принципом довіри спільноти, доброчесності і відповідальності. Інформація поширюється через коло осіб, які мають між собою не лише віртуальні зв'язки, а й реальні, а далі до їх віртуальних друзів, далі - до друзів друзів і т. д. Так люди краще сприймають інформацію, довіряють її правдивості. Масовий вплив на громадськість насамперед стосується питань безпеки, екології, здоров'я і життя людини, порушення прав, приниження честі і гідності. У соцмережах відбуваються громадські обговорення важливих політичних питань, організовують протестні акції, відстоюють права скривджених. За допомогою швидкого обміну інформацією відбувається пришвидшення реакції на ту чи іншу ситуацію з боку владних структур та інституцій. Соціальні медіа здатні відстоювати інтереси цілих верств населення, налагоджувати зв'язки між соціальними групами, контролювати дії влади, робити прозорими економічні рішення, забезпечувати громадську активність. I навіть коли користувачі соціальних мереж є суто споживачами інформації, не виявляючи жодної інтерактивності, їхня присутність у соціальній групі забезпечує вплив на їхню свідомість. Це відбувається внаслідок наслідування, що є найпоширенішою формою поведінки людини у міжособистісній взаємодії. Бажання наслідувати, орієнтуватися на певний приклад, копіювати поведінку людини якнайбільше здійснює процес соціалізації особистості. Причиною впливу може бути і навіювання, яке $є$ одною з найпоширеніших практик маніпуляції, звернене не до розуму, а до емоцій особи, беззастережного виконування закликів до дій. Іншим впливом на свідомість людини є мода, що диктує певні форми стандартизованої масової поведінки людей, що виникає стихійно під впливом настроїв, смаків, захоплень, які домінують у суспільстві. Бажання йти за модою викликає потужний вплив. Якщо брати до уваги соцмережі, то прикладом може слугу-

5 Онищенко, О.С, Горовий, В.М, та Попик, В.Ф. (2013), Соціальні мережі як чинник розвитку громадянського суспільства, НАН України, Нац. б-ка України ім. В. І. Вернадського, К., с. 27. 
вати поширення стандартних рамок на основну фотографію у мережі Facebook типу «Зупини капітуляцію», «Дякую захисникам України», «Пам’ятаємо про Голодомор», «Я пишу радіодиктант», зображення осінніх листочків, новорічних прикрас тощо. Мода дуже тісно пов'язана зі смаками та звичаями людей, тому у соцмережах часто фігурують сезонні фото, фото після голосування на виборах, фото з тваринками, фото $з$ квітами, фото святкового столу, новорічна і великодня тематика, відпочинок на морі тощо.

Ще одним потужним впливом на масову свідомість є чутки. Як правило, вони стосуються важливих для певної соціальної групи чи людини явищ, торкаються актуальних для них потреб та інтересів. Переказування чуток є неусвідомленим бажанням співдіяти у повідомленні чогось важливого та сенсаційного, виглядати поінформованим до моменту, коли переказана інформація буде загальновідомою. Часто у такий спосіб поширюються фейки, і до моменту їх спростування аудиторія настільки масштабно поширює цю інформацію, що не виникає жодного сумніву стосовно іiі правдивості. Парадоксально, що фейкові новини продовжують жити навіть після оприлюднення правди. Часом такі фейки не мають терміну придатності і вірусно поширюються групами по кілька разів. Все це через те, що хтось з учасників iз запізненням отримав інформацію, але бажає виконати заклик «поширити», тобто допомогти.

Великої популярності у соцмережах набувають порадні. Учасники мережевого спілкування тут можуть знайти не лише друзів чи однодумців, а й потрібного лікаря, репетитора, водія, який підвезе у пізню пору на околицю міста, героя ток-шоу або телевізійного сюжету. Можуть також знайти і загублені речі, документи і ключі. Обміняти невдалу покупку, віддати непотрібні речі за солодощі. А також отримати відповіді інтернет-спільноти, який фільм подивитися ввечері, у яке кафе запросити дівчину, який знеболювальний засіб краще прийняти, чи народжувати після 40..

Бажаючих дати пораду завжди достатньо. Люди не залишаються байдужими і навіть влаштовують дискусії, прагнучи довести кожен свою правоту. I попри абсурдність деяких запитань і відповідей, все ж громадська думка здатна підштовхнути до рішення, бо правдивість реакції на запит продиктована власним досвідом. Непідкупність опінії про лікаря чи вихователя в дитячому садочку спонукає до відповідних висновків, бо навмисне відстежити і спрогнозувати такі реакції навряд чи вдасться. Чому люди вдаються до таких методів пошуку вирішення своїх проблем швидкість і прозорість. Позитивна тенденція, що в мережі люди все більше проявляють свою небайдужість, сміливо висловлюють позицію, критикують. А все це сприяє розвитку громадянського суспільства, яке у країнах пострадянського простору мусить пройти шлях від замкнутості до відкритості. I саме соціальні медіа є тим першим щаблем відкритості, до якого суспільство має дорости через віртуальний світ у реальний.

Потужний інформаційний вплив соцмереж помітний і серед громадських ініціатив, коли потрібно зібрати відповідну кількість підписів для втілення проекту, здійснити голосування за певного кандидата, провести опитування чи анкетування, визначити рейтинги популярності.

Можливості соціальних медіа сьогодні настільки великі, що вони стали складовою масової комунікації, важливою інформаційною платформою, яка не лише інформує чи координує, а також впливає, задає тон, випереджаючи традиційні ме- 
діа. За даними Інституту масової інформації, кожну п’яту новину в центральних онлайн-медіа взято із соціальних мереж. Більшість - «Фейсбука»: 63\% матеріалів. $23 \%$ інформації взято з «Інстаграму». На «Твіттер» припадає 6,5\% матеріалів, на «Телеграм» та YouTube - 4,5 та 3\% відповідно 6 .

Чому традиційні 3МІ орієнтуються на інформацію з соцмереж? Це насамперед пов'язано зі зручністю моніторингу того, що діється навколо. По-друге - це швидкість поширення інформації; третє - зріз громадської думки про те, що є важливим сьогодні; четверте - пошук ексклюзивної інформації та нових поглядів на проблеми; п'яте - швидка взаємодія з аудиторією. Журналістам, як професійним комунікаторам, важливе першоджерело інформації, а їхня присутність у соцмережах тільки збільшує популярність видання і допомагає зміцнити зв'язки з аудиторією, залучити додатковий контент. Наприклад, в інтернет-версії «Високого Замку» в розділі блоги знаходимо передруки з дописів у мережі Facebook Аркадія Бабченка, Михайла Басараба, Юрія Винничука та ін.

Соціальні медіа у певний спосіб допомагають впоратися з великим обсягом інформації, оперативно виконати запит на інформацію. 3 одного боку, це значно спрощує пошук новин, а з іншого - ускладнює їхню верифікацію. До прикладу, як часто ЗМІ передруковують інформацію з фейкових сторінок, як це було свого часу зі сторінкою у Facebook Ігоря Коломойського про націоналізацію Приватбанку.

Мас-медіа часто послуговуються інформацією з соцмереж відомих посадовців і політиків. Передруки твітів $є$ важливою складовою медіаконтенту і це не лише українська практика, а й закордонна теж. Однак, як стверджують фахівці, «інформаційне середовище соціальних мереж з огляду на його зростаючу впливовість на свідомість користувачів поступово стає також об’єктом впливу громадських організацій, владних структур, бізнесу. Воно також стає об'єктом маніпулятивних технологій, негативних інформаційних впливів»?

Саме тому у статті ми брали до уваги сторінки соцмереж людей, які самі створюють контент, бо вже поширеною стала практика ведення сторінок відомих політиків, письменників, зірок естради третіми особами, але це вже особливості медіамаркетингу.

Підсумовуючи, можемо зробити висновок, що сьогодні соціальні медіа впевнено зайняли свою нішу у масово-комунікаційній сфері. 3 огляду на це на часі нові дослідження у цій царині. Зі сказаного вище випливає, що соціальні медіа здобувають популярність не лише у потенційних підписників, а й у професійних журналістів. Той факт, що соціальні мережі мають потужну силу впливу на масову свідомість, спонукає не втрачати пильність, адже цим можуть скористатися маніпулятори. Позитивним чинником є те, що соціальні медіа стали фундаментом розвитку громадянського суспільства. Через масовий вплив на громадську думку здійснюється оперативне інформування та консолідація громадян навколо важливих питань як державного, так і соціального характеру.

6 Іщенко, Н. (2019), «Чим небезпечні нові медіа і що з цим робити», доступно за адресою: https://m. day.kyiv.ua/uk/article/media/socmerezhi-i-my

7 Онищенко, О. С, Горовий, В. М, та Попик, В. Ф. (2013), Соціальні мережі як чинник розвитку громадянського суспільства, НАН України, Нац. Б-ка України ім. В.І.Вернадського, К., с. 14. 


\section{СПИСОК ЛІТЕРАТУРИ}

1. Гвоздєв, В. М. (2013), «Блогінг як вияв і знаряддя громадянської журналістики», Вісник Львівського ун-ту Серія журн., вип. 38, с. 469-476.

2. Городенко , Л. М. (2014), «Комунікативні парадигми розвитку мережевих соціальних спільнот», Інформаційне суспільство, вип. 19, с. 68-72.

3. Іщенко, Н. (2019), «Чим небезпечні нові медіа і що з цим робити», доступно за адресою: https://m.day.kyiv.ua/uk/article/media/socmerezhi-i-my (останній перегляд 9 листопада 2019)

4. Онищенко, О.С, Горовий, В.М, та Попик, В.Ф. (2013), Соціальні мережі як чинник розвитку громадянського суспільства, НАН України, Нац. Б-ка України ім. В. І.Вернадського, К., 220 с.

5. Фісенко, Т. В. (2010), «Соціальні інтернет-мережі як засіб задоволення інформаційних потреб», Наукові записки Інституту журналістики, Т. 41, доступно за адресою: http://www.nbuv.gov.ua/portal/soc_gum/nzizh/2010_41/Fisenko.pdf (останній перегляд 5 листопада 2019).

6. Social Media and its Origins, available at: http://www.defence.gov.au/pathwaytochange/ Docs/SocialMedia/1.\%20Social\%20media\%20and\%20its\%20origins\%20SM.p.my (ocтанній перегляд 6 листопада 2019).

\section{REFERENCES}

1. Gvozdiev, V. M. (2013), «Blogging as a sign and an instrument of citizen journalism», Visnyk of the Lviv University. Series Journalism, issue 38, pp. 469-476.

2. Horodenko, L. M. (2014), «Communication paradigms of development of social networking communities», Information society, issue 19, pp. 68-72.

3. Ishchenko, H. (2019), "Chym nebezpechni media I shcho z tsym robyty», URL: https://m.day.kyiv.ua/uk/article/media/socmerezhi-i-my (accessed 09 November 2019).

4. Onyshchenko, O. S, Horovyy, V. M, and Popyk, V. F. (2013), Sotsial'ni merezhi yak chynnyk rozvytku hromadyans'koho suspil'stva, NAN Ukrayiny, Nats. B-ka Ukrayiny im. V.I.Vernads'koho, K., 220pp.

5. Social Media and its Origins, available at: http://www.defence.gov.au/pathwaytochange/ Docs/SocialMedia/1.\%20Social\%20media\%20and\%20its\%20origins\%20SM.p. (accessed 06 November 2019).

6. Fisenko, T. V. (2010). «Sotsialni internet-merezhi yak zasib zadovolennya Informatsiynih potreb», Naukovi zapiski Institutu zhurnalistiki, 41. URL: http://www.nbuv.gov.ua/ portal/soc_gum/nzizh/2010_41/Fisenko.pdf (accessed 05 November 2019) 


\title{
THE INFLUENCE OF SOCIAL MEDIA ON THE FORMATION OF PUBLIC OPINION
}

\author{
Myroslava Rudyk \\ Ivan Franko National University of Lviv, \\ Generala Chuprynky Str. 49, 79044, Lviv, Ukraine \\ e-mail: rudykmiroslava@ukr.net \\ https://orcid.org/0000-0003-3612-100X
}

In the article, the scientist explores the role of social media in the process of forming public opinion. She defines public opinion as an element of the social system. She analyzes the principles of disseminating information in social media. She studies the content of information messages and the role of public opinion as a source of information or an information occasion in the media.

An important issue that arose from the popularity of social media is that traditional media not only have the opportunity to promote their brand through social networks, disseminate information, but also attract an audience to mass discussion of issues, and study, and subsequently influence public opinion. After all, the consumption of information has gradually become interactive: it is important for the user to interact with the media, instantly show a reaction and attitude to the content. It is this user reaction that is an important part of news distribution.

The audience of social networks is gradually involved in various professional journalistic procedures by participating in discussions, producing informational occasions and additional content. It often happens that the reader's feedback becomes more interesting and significant than the original message. Therefore, the media are increasingly turning to unofficial sources to find the right information. The active development of social networks, which have already become an integral part of the communication system, is forcing journalists to use these platforms to create new forms of presentation, ways of contact with the reader.

Therefore, the role of social media is primarily reduced to communication and exchange of information. However, do not underestimate the powerful impact on the mass consciousness, which manifests itself both at the personal level of social activity, and at the sociable. And today, some media outlets have mastered this and are successfully applying it in their work with the audience.

Key words: social media; public opinion; influence; public relations. 